\title{
Physical, Spectroscopic and Thermal Characterization of Biofield Treated Fish Peptone
}

\author{
Mahendra Kumar Trivedi ${ }^{1}$, Alice Branton ${ }^{1}$, Dahryn Trivedi ${ }^{1}$, Gopal Nayak ${ }^{1}, \operatorname{Ragini} \operatorname{Singh}^{2}$, \\ Snehasis Jana ${ }^{2, *}$ \\ ${ }^{1}$ Trivedi Global Inc., Henderson, USA \\ ${ }^{2}$ Trivedi Science Research Laboratory Pvt. Ltd., Bhopal, Madhya Pradesh, India
}

Email address:

publication@trivedisrl.com (S. Jana)

\section{To cite this article:}

Mahendra Kumar Trivedi, Alice Branton, Dahryn Trivedi, Gopal Nayak, Ragini Singh, Snehasis Jana. Physical, Spectroscopic and Thermal Characterization of Biofield Treated Fish Peptone. European Journal of Biophysics. Vol. 3, No. 6, 2015, pp. 51-58.

doi: $10.11648 /$ j.ejb.20150306.12

\begin{abstract}
The by-products of industrially processed fish are enzymatically converted into fish protein isolates and hydrolysates having a wide biological activity and nutritional properties. However, the heat processing may cause their thermal denaturation thereby causing the conformational changes in them. The present study utilized the strategy of biofield energy treatment and analysed its impact on various properties of the fish peptone as compared to the untreated (control) sample. The fish peptone sample was divided into two parts; one part was subjected to Mr. Trivedi's biofield treatment, coded as the treated sample and another part was coded as the control. The impact of biofield treatment was analysed through various analytical techniques and results were compared with the control sample. The particle size data revealed $4.61 \%$ increase in the average particle size $\left(\mathrm{d}_{50}\right)$ along with $2.66 \%$ reduction in the surface area of the treated sample as compared to the control. The X-ray diffraction studies revealed the amorphous nature of the fish peptone sample; however no alteration was found in the diffractogram of the treated sample with respect to the control. The Fourier transform infrared studies showed the alterations in the frequency of peaks corresponding to $\mathrm{N}-\mathrm{H}, \mathrm{C}-\mathrm{H}, \mathrm{C}=\mathrm{O}, \mathrm{C}-\mathrm{N}$, and $\mathrm{C}-\mathrm{OH}$, functional groups in the treated sample as compared to the control. The differential scanning calorimetry data revealed the increase in transition enthalpy $(\Delta \mathrm{H})$ from $-71.14 \mathrm{~J} / \mathrm{g}$ (control) to $-105.32 \mathrm{~J} / \mathrm{g}$ in the treated sample. The thermal gravimetric analysis data showed the increase in maximum thermal degradation temperature $\left(\mathrm{T}_{\max }\right.$ ) from $213.31^{\circ} \mathrm{C}$ (control) to $221.38^{\circ} \mathrm{C}$ along with a reduction in the percent weight loss of the treated sample during the thermal degradation event. These data revealed the increase in thermal stability of the treated fish peptone and suggested that the biofield energy treatment may be used to improve the thermal stability of the heat sensitive compounds.
\end{abstract}

Keywords: Fish Peptone, Biofield Energy Treatment, Protein Hydrolysate, Differential Scanning Calorimetry, Thermogravimetric Analysis

\section{Introduction}

The fisheries industry is a major source of income for various countries worldwide. However, the industrially processed fish that is utilized for human consumption yields more than 3.17 million tons by-products per year [1]. These by-products require proper disposal and hence creates the huge revenue loss to the seafood industry [2]. Therefore, the emphasis was done to find the new uses for these waste byproducts. In recent years, several advancements in biotechnology field utilize the marine by-products and convert them into some product of interest [3]. It includes their conversion in protein isolates and hydrolysates having functional food properties and natural food antioxidants [4]. The protein converts into smaller peptides through enzymatic conversion and their breakdown products yield protein hydrolysates. Many researchers have reported the biological activity and nutritional values of protein hydrolysates through their bioactive peptides $[5,6]$.

The peptones are a mixture of polypeptides and amino acids that are used in several biotechnological applications. They are derived from the acid or enzymatic hydrolysis of natural products such as bovine or porcine meat, milk, yeasts, and plants. The peptones are mainly used in the production of 
media for fermentation, tissue culture, and vaccine stabilizers [7]. The main source of peptone is animal tissues; however it faces the problem of bovine spongiform encephalopathy, a neurodegenerative disease and commonly known as mad cow disease. The main cause of this disease is a specific type of misfolded protein, prion and transmitted to the healthy animals through infected sheep and goats [8]. The problems related to animal tissue peptones and their increased demand as raw material focuses the attention towards fish peptones due to their non-meat origin, free from swine-flu, and inexpensive, as derived from fish by-products $[9,10]$. Further researches proved fish peptone as a source of high protein and a balance of amino acids, hence used as the main source of industrial peptones. The peptones as a source of nitrogen become the most expensive part of growth media in the fermentation industry [11]. Besides, during processing such kind of products are subjected to various thermal treatments to inactivate the antinutritional factors, remove allergens, and to obtain the required solubility and texture [12]. However, they may face the problem of some conformational changes due to their thermal denaturation during heating that might affect their solubility, stability, and shelf-life [13, 14]. Therefore, it creates the need for some alternative strategies that may help to improve the stability related issues of this compound in a cost-effective manner.

The biofield energy treatment was reported as a measure for increasing the thermal stability of some organic products [15]. It is a putative form of energy that surrounds the body of all living organisms and can be exchanged with the environment $[16,17]$. A human can harness the energy from the environment or universe and can transmit it to any living or non-living object. The object(s) will receive the energy and respond to useful way, this process is termed as biofield treatment. It is reported for the efficacy and benefits in cancer and arthritis patients $[18,19]$. Moreover, Mr. Trivedi is also well known for his unique biofield energy treatment, The Trivedi Effect ${ }^{\circledR}$. It was reported for its impact on the plants [20], microorganisms [21], and culture medium [22]. Hence, the present work was aimed to treat the fish peptone by Mr. Trivedi's biofield energy and evaluate the impact on the physicochemical properties and stability of the fish peptone using various analytical techniques viz. particle size analyser, surface area analyser, X-ray diffraction, Fourier transform infrared spectroscopy, UV-visible spectroscopy, differential scanning calorimetry, and thermogravimetric analysis.

\section{Materials and Methods}

The fish peptone was procured from HiMedia Laboratories, India. In treatment methodology, the fish peptone sample was divided into two equal parts in which one part was coded as the control and another part as the treated. The treated part was handed over in sealed pack to Mr. Trivedi under standard laboratory conditions. Mr. Trivedi provided the biofield energy treatment to this part (treated) through his unique energy transmission process, without touching the sample. The control part was kept untreated. The impact of biofield treatment on the treated sample was subsequently analysed as compared to the control sample using various analytical techniques.

\subsection{Particle Size Analysis}

The SYMPATEC HELOS-BF laser particle size analyser was used for the determination of particle size of the control and treated samples. The analyser was having a detection range of $0.1 \mu \mathrm{m}$ to $875 \mu \mathrm{m}$. The parameters determined in the analysis were $d_{50}$ (average particle size) and $d_{99}$ (size below which $99 \%$ of the particles are present).

\subsection{Surface Area Analysis}

The Brunauer-Emmett-Teller (BET) surface area analyser, Smart SORB 90 was used to calculate the surface area of the control and treated samples.

\subsection{X-Ray Diffraction (XRD) Study}

The X-ray powder diffractograms were recorded using Phillips Holland PW 1710 X-ray diffractometer that uses $1.54056 \AA$ wavelength of radiation. The $\mathrm{X}$-ray generator was operating at $35 \mathrm{kV}$ and $20 \mathrm{~mA}$ and equipped with a copper anode with nickel filter. The diffractograms of control and treated samples were analysed to determine the nature of the sample, i.e. crystalline or amorphous and XRD of treated sample was compared with the control to analyse any difference between them.

\subsection{Fourier Transform-Infrared (FT-IR) Spectroscopic Characterization}

The Shimadzu's Fourier transform infrared spectrometer (Japan) was used for recording the FT-IR spectra of the control and treated samples in the frequency range 4000-450 $\mathrm{cm}^{-1}$. The spectra were obtained in the form of wavenumber $(1 / \mathrm{cm})$ vs. percent transmittance $(\% \mathrm{~T})$. The peaks obtained from the spectra of control and treated samples were assigned on the basis of functional groups present in the sample. The frequency of the peaks corresponding to the functional groups were compared in the control and treated samples for analysing the impact of biofield energy with respect to the bond length and bond angle of those functional groups.

\subsection{UV-Visible (UV-Vis) Spectroscopic Characterization}

The UV-Vis spectral analysis was carried out using Shimadzu UV-2400 PC series spectrophotometer. The spectra of the control and treated samples were recorded using $1 \mathrm{~cm}$ quartz cell that has a slit width of $2.0 \mathrm{~nm}$.

\subsection{Differential Scanning Calorimetric (DSC) Analysis}

The DSC analysis of control and treated samples was carried out using model Perkin Elmer/Pyris-1. The samples were heated at a rate of $10^{\circ} \mathrm{C} / \mathrm{min}$ under air atmosphere $(5$ $\mathrm{mL} / \mathrm{min}$ ). The thermograms were collected over the 
temperature range of $50^{\circ} \mathrm{C}$ to $300^{\circ} \mathrm{C}$. Any differences in the transition temperature and transition enthalpy were recorded from the thermogram to determine the impact of biofield energy treatment on the treated sample with respect to the control.

\subsection{Thermogravimetric Analysis / Derivative Thermogravimetry (TGA/DTG)}

The thermal stability profile of fish peptone was analysed using Mettler Toledo simultaneous thermogravimetric analyser (TGA/DTG). The temperature range was selected from room temperature to $400^{\circ} \mathrm{C}$ and a heating rate of $5^{\circ} \mathrm{C} / \mathrm{min}$ under air atmosphere. The impact of biofield treatment was analysed by comparing the pattern of degradation, maximum degradation temperature, and percent weight loss of the treated sample as compared to the control sample.

\section{Results and Discussion}

\subsection{Particle Size Analysis}

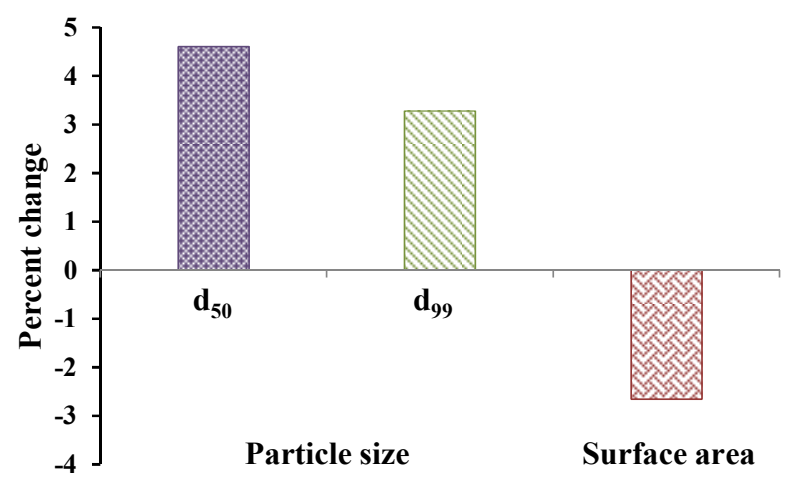

Fig. 1. Percent change in particle size and surface area of the treated fish peptone as compared to the control.

The particle size analysis data depicted that the $\mathrm{d}_{50}$ and $\mathrm{d}_{99}$ were 23.44 and $120.17 \mu \mathrm{m}$, respectively in the control sample. However, in treated sample, the $\mathrm{d}_{50}$ and $\mathrm{d}_{99}$ were

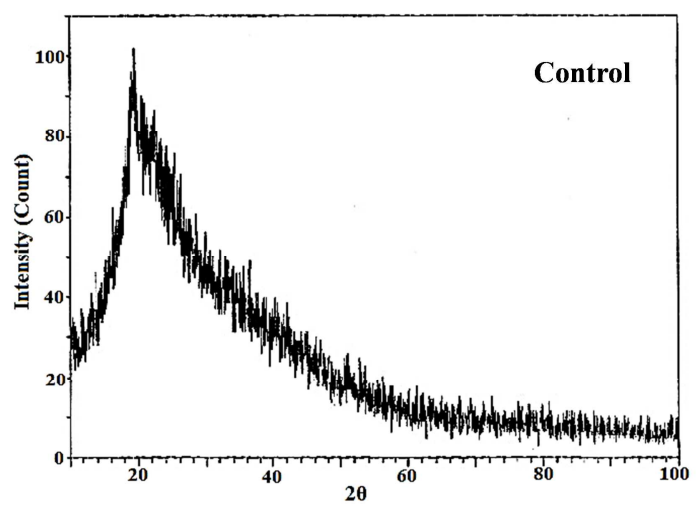

Fig. 2. X-ray diffractograms of control and treated samples of fish peptone.

\subsection{FT-IR Spectroscopic Analysis}

The FT-IR spectra of fish peptone (control and treated samples) are shown in Fig. 3. The fish peptone contains mainly proteins and carbohydrates [27]. Hence, the major found as 24.52 and $124.11 \mu \mathrm{m}$, respectively. The percent change observed in the particles sizes of the biofield treated sample with respect to the control is depicted in Fig. 1. It revealed that $\mathrm{d}_{50}$ was increased by $4.61 \%$, and $\mathrm{d}_{99}$ was increased by $3.28 \%$ in the treated sample as compared to the control. The protein molecules have a tendency to aggregate through the weak interactions [23]. Moreover, the temperature has a significant impact on the aggregation rate [24]. Hence, it is assumed that the biofield energy treatment might provide some energy to the sample that resulted in the slight increase in the particle size of the treated sample through the process of aggregation.

\subsection{Surface Area Analysis}

The surface area of control and treated samples of fish peptone was investigated using BET method. The data reported that the control sample had a surface area of 0.188 $\mathrm{m}^{2} / \mathrm{g}$; however, the treated sample had a surface area of 0.183 $\mathrm{m}^{2} / \mathrm{g}$. It showed that the surface area was decreased by $2.66 \%$ (Fig. 1) in the treated sample as compared to the control. The effective surface area is inversely related to the particle size of the compound [25]. Thus, the slight decrease in surface area might be attributed to the increase in the particle size of the treated sample after biofield treatment.

\subsection{X-Ray Diffraction (XRD)}

The X-ray powder diffractograms of control and treated samples of fish peptone are shown in Fig. 2. The XRD pattern of the control sample did not contain any diffraction maxima, which indicated that the molecules were internally disordered and glassy in nature. The glassy material showed one broad peak that resulted due to short range ordering of the molecules as compared to the long-range order in a crystal [26]. The diffractogram of the treated sample also showed similar XRD pattern indicated that biofield energy treatment may not cause any alteration in the ordering of the molecules of fish peptone sample.

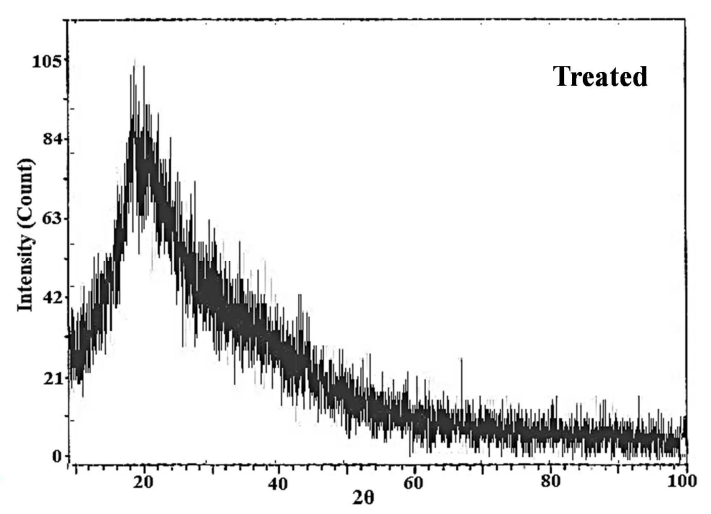

vibration peaks observed (Table 1) were assigned to the functional groups present in these ingredients. The peak at $3080 \mathrm{~cm}^{-1}$ in the control sample was assigned to $\mathrm{NH}_{3}{ }^{+}$ antisymmetric stretching of amino acids; however the peak 
might get merged with the C-H stretching peaks [28]. Besides, in the treated sample the peak was shifted to a lower frequency at $3066 \mathrm{~cm}^{-1}$. Similarly, the $\mathrm{C}-\mathrm{H}$ stretching peaks of carbohydrates were appeared at 2993 and $2893 \mathrm{~cm}^{-1}$ in the control sample, whereas, in the treated sample, the peaks were appeared at 2976 and $2885 \mathrm{~cm}^{-1}$. Besides, the $\mathrm{C}-\mathrm{H}$ stretching peak of $\mathrm{CH}_{2}$ group attached to -O- of lactone ring present in carbohydrate was observed at higher frequency i.e. at $2835 \mathrm{~cm}^{-1}$ as compared to the control $\left(2815 \mathrm{~cm}^{-1}\right)$. The peak observed at $1753 \mathrm{~cm}^{-1}$ in the control sample was assigned to the $\mathrm{C}=\mathrm{O}$ stretching of the lactone ring that was not observed in the treated sample. Moreover, the peak at $1635 \mathrm{~cm}^{-1}$ in the control was assigned to the $\mathrm{NH}_{2}$ deformation and $\mathrm{C}=\mathrm{O}$ stretching of the amide present in the peptone. However, the corresponding peak was shifted to $1643 \mathrm{~cm}^{-1}$ in the treated sample. Similarly, the peak observed at $1589 \mathrm{~cm}^{-1}$ in the control sample was assigned to the $\mathrm{NH}_{2}$ deformation of amino acids and ring stretching of the benzene ring. The corresponding peak was appeared at 1579 $\mathrm{cm}^{-1}$ in the treated sample. The peaks due to aliphatic $\mathrm{CH}_{3}$ scissoring and bending were observed at 1438 and $1340 \mathrm{~cm}^{-1}$ in the control sample; however the corresponding peaks were observed at 1458 and $1342 \mathrm{~cm}^{-1}$ in the treated sample. The O$\mathrm{H}$ in-plane bend and $\mathrm{C}-\mathrm{N}$ stretching of amide group present in amino acids showed a peak at $1400 \mathrm{~cm}^{-1}$ in the control and $1402 \mathrm{~cm}^{-1}$ in the treated sample. Similarly, the -C-O-Cstretching peak of the lactone ring was observed at 1245 and $1247 \mathrm{~cm}^{-1}$ in the control and treated samples, respectively [28]. Besides, the N-H bending peak of pyrrole ring C-N stretching peak of pyrazole ring present in proteins was appeared at $1151 \mathrm{~cm}^{-1}$ in the control sample $[29,30]$; whereas at $1118 \mathrm{~cm}^{-1}$ in the treated sample. The $\mathrm{C}-\mathrm{OH}$ stretching peak of carbohydrates was observed at $1072 \mathrm{~cm}^{-1}$ in the control and $1085 \mathrm{~cm}^{-1}$ in the treated sample. The C-H out of plane bending peak of pyrazole ring in was observed at the same frequency in both the control and treated samples i.e. at 921 $\mathrm{cm}^{-1}$. Similarly, the peaks due to $\mathrm{O}=\mathrm{C}-\mathrm{O}$ bend of carboxylic acid and $-\mathrm{N}-\mathrm{C}=\mathrm{O}$ bend of amide group present in amino acids were observed at nearly same frequencies in both the samples i.e. at 617 and $536 \mathrm{~cm}^{-1}$ in the control and 619 and $536 \mathrm{~cm}^{-1}$ in the treated sample, respectively.

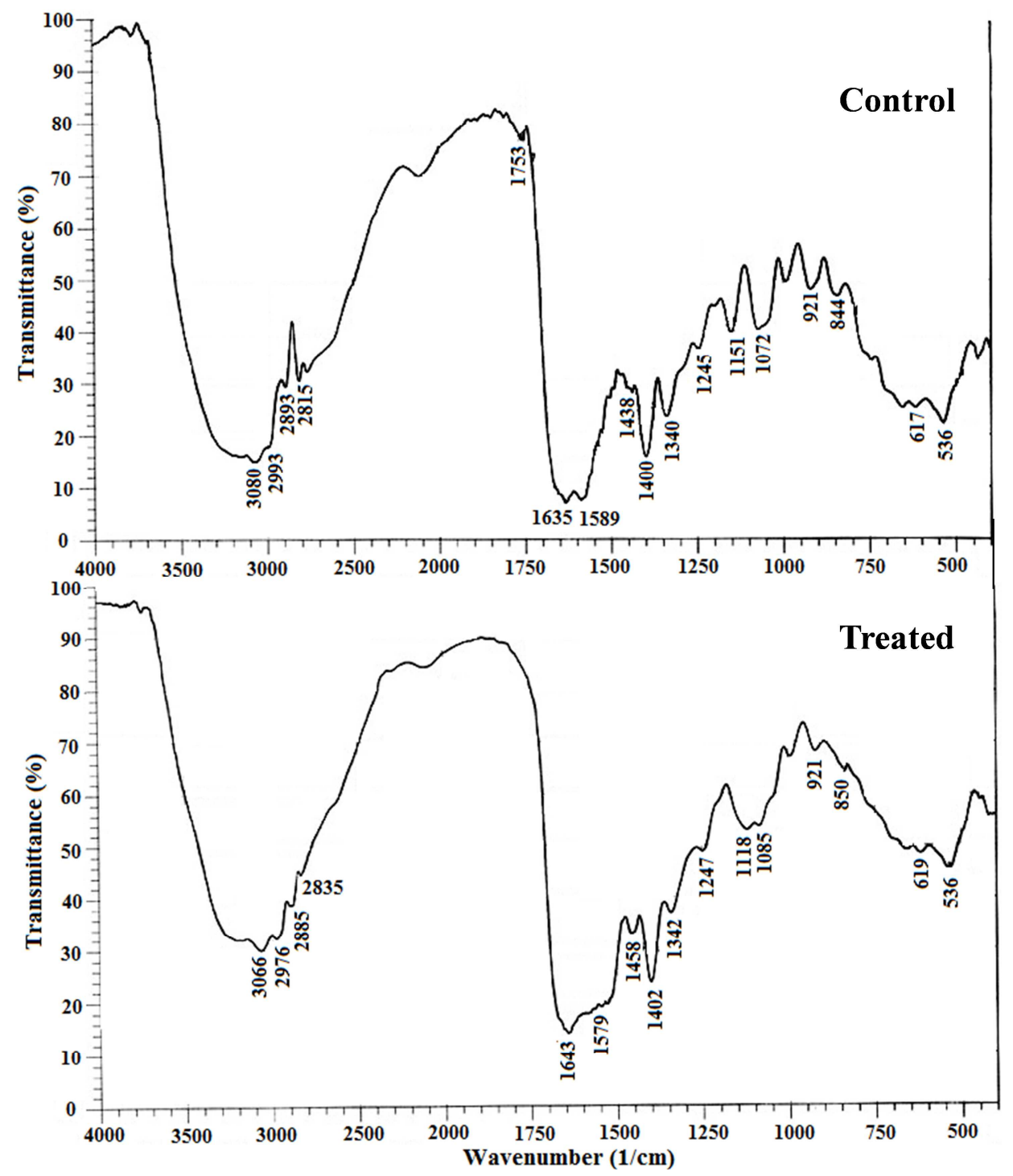

Fig. 3. FT-IR spectra of control and treated samples of fish peptone. 
Table 1. Vibration modes observed in fish peptone.

\begin{tabular}{|c|c|c|c|}
\hline \multirow{2}{*}{$\begin{array}{l}\text { S. } \\
\text { No. }\end{array}$} & \multirow{2}{*}{ Functional group } & \multicolumn{2}{|c|}{ Wavenumber $\left(\mathrm{cm}^{-1}\right)$} \\
\hline & & Control & Treated \\
\hline 1 & $\mathrm{NH}_{3}{ }^{+}$stretching & 3080 & 3066 \\
\hline 2 & $\mathrm{C}-\mathrm{H}$ stretching & $\begin{array}{l}2993 \\
2893\end{array}$ & $\begin{array}{l}2976 \\
2885\end{array}$ \\
\hline 3 & C-H stretching & 2815 & 2835 \\
\hline 4 & $\mathrm{C}=\mathrm{O}$ stretching (lactone) & 1753 & ND \\
\hline 5 & $\mathrm{NH}_{2}$ deformation, $\mathrm{C}=\mathrm{O}$ stretching & 1635 & 1643 \\
\hline 6 & $\begin{array}{l}\mathrm{NH}_{2} \text { deformation, } \\
\text { Ring stretching (benzene) }\end{array}$ & 1589 & 1579 \\
\hline 7 & $\mathrm{CH}_{3}$ bending & $\begin{array}{l}1438, \\
1340\end{array}$ & $\begin{array}{l}1458 \\
1342\end{array}$ \\
\hline 8 & $\begin{array}{l}\mathrm{O}-\mathrm{H} \text { in plane bend, } \\
\mathrm{C}-\mathrm{N} \text { stretching (amide) }\end{array}$ & 1400 & 1402 \\
\hline 9 & C-O-C stretching (lactone) & 1245 & 1247 \\
\hline 10 & $\begin{array}{l}\mathrm{N}-\mathrm{H} \text { bending, } \mathrm{C}-\mathrm{N} \text { stretching } \\
\text { (heterocyclic ring) }\end{array}$ & 1151 & 1118 \\
\hline 11 & $\mathrm{C}-\mathrm{OH}$ stretching & 1072 & 1085 \\
\hline 12 & C-H out of plane bend (heterocyclic ring) & 921 & 921 \\
\hline 13 & $\mathrm{O}=\mathrm{C}-\mathrm{O}$ bending & 617 & 619 \\
\hline 14 & $\mathrm{~N}-\mathrm{C}=\mathrm{O}$ bending $(\mathrm{amide})$ & 536 & 536 \\
\hline
\end{tabular}

The observation showed the alterations in the frequency of several peaks in the treated sample such as $\mathrm{N}-\mathrm{H}, \mathrm{C}-\mathrm{H}, \mathrm{C}=\mathrm{O}$, $\mathrm{C}-\mathrm{N}, \mathrm{C}-\mathrm{OH}$, etc. as compared to the control. It revealed that the biofield energy treatment might have an impact on the bond length, bond angle, or dipole moment of the corresponding functional groups in the treated sample. However, further analysis is required to determine the effect of biofield energy on the particular functional group and its impact on the properties of fish peptone sample.

\subsection{UV-Vis Spectroscopic Analysis}

The UV spectrum of control sample showed the absorption peak at $\lambda_{\max }$ equal to $258 \mathrm{~nm}$. The biofield treated sample also showed absorption peak at similar wavelength i.e. 259 $\mathrm{nm}$. It showed that the biofield energy treatment had not affected the $\mathrm{HOMO} \rightarrow$ LUMO transition within the components of fish peptone sample.

\subsection{DSC Analysis}

The DSC thermograms of control and treated samples of fish peptone are presented in Fig. 4. The thermogram of control sample showed a broad endothermic peak in the range of $193^{\circ} \mathrm{C}-197^{\circ} \mathrm{C}$. The broadness of peak confirmed the amorphous nature of the sample as evident from the XRD studies. Moreover, the DSC can be used in the evaluation of stability of the sample by determining the temperature at the maximum point of the endothermic curve $\left(T_{m}\right)$ [31]. The DSC thermogram of the control sample showed $\mathrm{T}_{\mathrm{m}}$ at $197.14^{\circ} \mathrm{C}$. This temperature can be considered as the denaturation temperature of the control sample [32]. Furthermore, the treated sample showed the endothermic curve in the range of $189^{\circ} \mathrm{C}-200^{\circ} \mathrm{C}$ and the $\mathrm{T}_{\mathrm{m}}$ was reported at $197.20^{\circ} \mathrm{C}$. The results of control and treated samples do not reveal any significant alteration in the denaturation temperature $\left(\mathrm{T}_{\mathrm{m}}\right)$; however, the major difference was observed in the transition enthalpy $(\Delta \mathrm{H})$ during this event. The control sample showed the $\Delta \mathrm{H}$ of $-71.14 \mathrm{~J} / \mathrm{g}$ whereas; the treated sample showed $\Delta \mathrm{H}$ of $-105.32 \mathrm{~J} / \mathrm{g}$. It revealed that the biofield treated sample required $31.14 \mathrm{~J} / \mathrm{g}$ more energy to undergo the process of denaturation that might be related to the increased thermal stability of the treated sample as compared to the control.
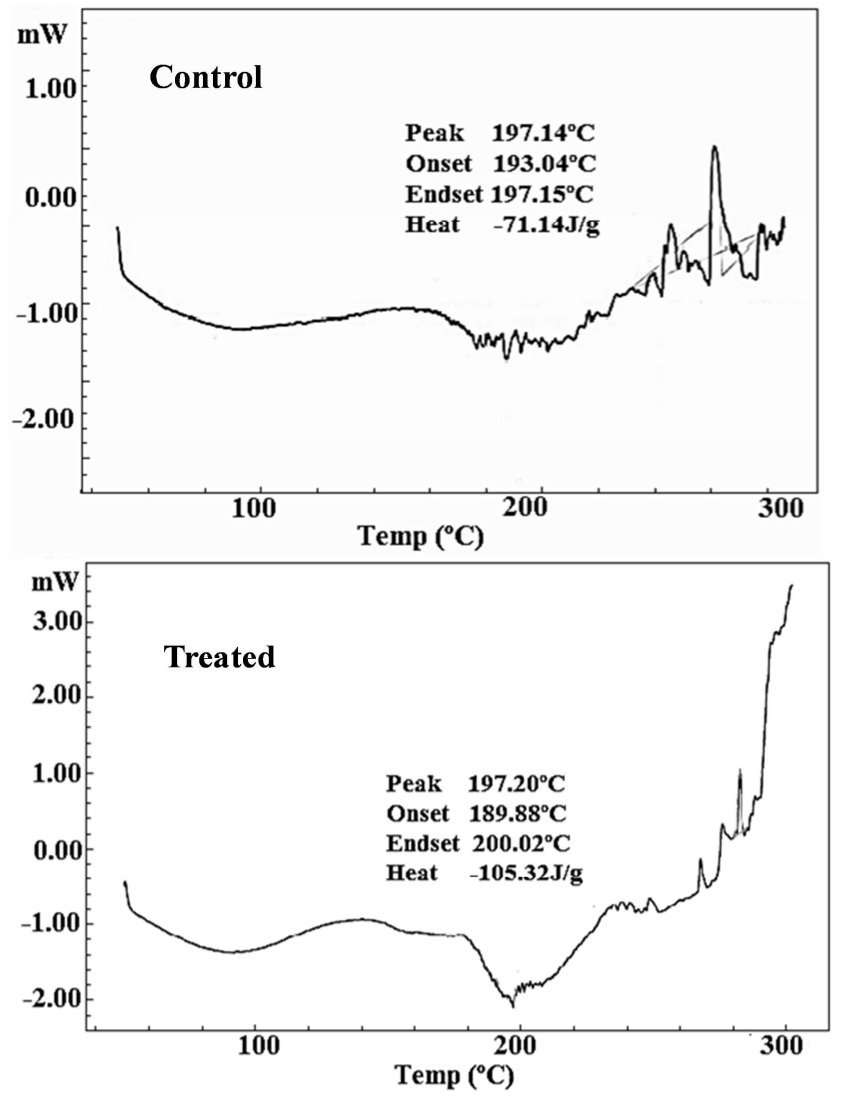

Fig. 4. DSC thermograms of control and treated samples of fish peptone.

\subsection{TGA/DTG Analysis}

The TGA/DTG studies analyse the change in the mass of the sample and thereby measure the physical or chemical changes that may occur within the sample during the heat treatment. This method is also used as a complementary to the DSC technique [33]. These techniques were used to determine the thermal stability of the sample. The TGA/DTG thermograms of the control and treated samples of fish peptone are reported in Fig. 5. The TGA thermograms of both samples showed the presence of two-step degradation. In the control sample, the first step showed an onset temperature of $195^{\circ} \mathrm{C}$ and an endset of about $240^{\circ} \mathrm{C}$, which involved a weight loss of $16.76 \%$ of the sample. On the other hand, the treated sample showed an onset temperature of $193^{\circ} \mathrm{C}$ and the endset of $250^{\circ} \mathrm{C}$ with a weight loss of $12.96 \%$ 
in the first step of degradation. The TGA results were similar to the data revealed by DSC studies and suggested that the onset temperature of weight loss in control and treated samples were due to the thermal degradation of the samples. However, the treated sample lost less weight as compared to the control sample that might be due to increase in the thermal stability of the treated sample after biofield treatment. Moreover, the second step of degradation in the control sample commenced at $260^{\circ} \mathrm{C}$ is also delayed by $8^{\circ} \mathrm{C}$ and observed at $268^{\circ} \mathrm{C}$ in the treated sample. Besides, DTG thermogram data showed that $\mathrm{T}_{\max }$ was observed at $213.31^{\circ} \mathrm{C}$ in the control sample while $221.38^{\circ} \mathrm{C}$ in the treated fish peptone. It indicated that $\mathrm{T}_{\max }$ was increased in the treated sample as compared to the control. Furthermore, the reduction in percent weight loss and the increase in $T_{\max }$ in the treated sample of fish peptone with respect to the control sample may be correlated with the increased thermal stability. The biofield treatment was also reported for increasing the thermal stability in casein enzyme hydrolysate and casein yeast peptone [34]. Hence, it is assumed that the biofield energy treatment might induce the aggregation of the molecules of treated sample through the weak intermolecular interactions that resulted in increased thermal stability. Besides, as reported earlier, during processing the thermal treatment can cause the denaturation of such type of compounds and result in the conformational changes. These changes might affect the solubility and stability of compound along with their long term storage [13, 14]. Hence, the biofield treatment might be used as an effective measure to increase the thermal stability, thereby increasing the stability, efficacy and shelf-life of these compounds.

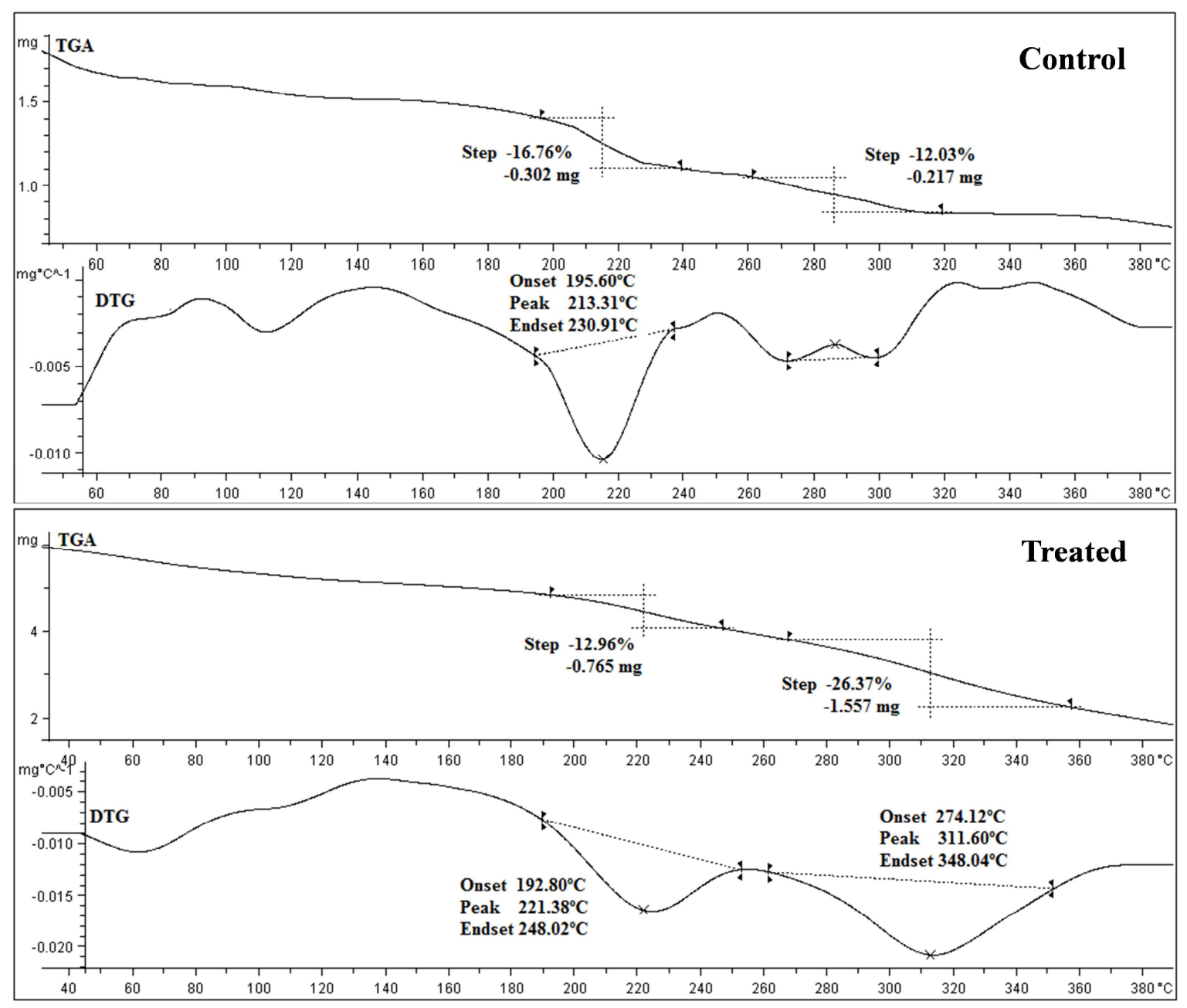

Fig. 5. TGA/DTG thermogram of control and treated samples of fish peptone.

\section{Conclusions}

The biofield treated fish peptone reported the increased particle sizes $\left(d_{50}\right.$ and $\left.d_{99}\right)$ suggesting the aggregation of molecules that might occur due to the impact of biofield energy. The slight reduction in surface area was also revealed in the treated sample as compared to the control that supported the impact of biofield energy on the particle size. The XRD studies revealed the amorphous nature of fish peptone sample; however no significant alteration was observed in the diffractogram of treated sample as compared to the control. The FT-IR spectroscopy results suggested some alteration in the frequency of peaks of various functional groups in the treated sample such as $\mathrm{N}-\mathrm{H}, \mathrm{C}-\mathrm{H}, \mathrm{C}=\mathrm{O}, \mathrm{C}-\mathrm{N}, \mathrm{C}-\mathrm{OH}$, etc. that 
may be due to the impact of biofield energy treatment on the bond length, bond angle, or the dipole moment corresponding to these groups. Moreover, the DSC analysis revealed the increase in transition enthalpy during degradation of the treated sample that suggested the increased need for energy by the treated sample to undergone the degradation process as compared to the control. The TGA/DTG studies depicted the increase in $T_{\max }$ and reduced percent weight loss of the treated sample as compared to the control. Hence, the DSC and TGA/DTG studies showed the increased thermal stability of the treated sample. Thus, it can be concluded that the biofield treated fish peptone sample may be more thermally stable as compared to the control, and the biofield energy treatment could be used as an alternative strategy for improving the thermal stability of different compounds.

\section{Acknowledgements}

The authors would like to acknowledge the whole team from the Sophisticated Analytical Instrument Facility (SAIF), Nagpur and MGV Pharmacy College, Nashik for providing the instrumental facility. Authors also greatly acknowledge the support of Trivedi Science, Trivedi Master Wellness and Trivedi Testimonials in this research work.

\section{References}

[1] Ferraro V, Cruz IB, Jorge RF, Malcata FX, Pintado ME, et al. (2010) Valorisation of natural extracts from marine source focused on marine by-products: A review. Food Res Int 43: $2221-2233$.

[2] Dekkers E, Raghavan S, Kristinsson HG, Marshall MR (2011) Oxidative stability of mahi mahi red muscle dipped in tilapia protein hydrolysates. Food Chem 124: 640-645.

[3] Galvez RP, Berge JP (2013) By-products from fish processing: Focus on French industry. Utilization of fish waste. CRC Press, Taylor \& Francis Group, New York.

[4] Kristinsson HG, Rasco BA (2000) Fish protein hydrolysates: Production, biochemical, and functional properties. Crit Rev Food Sci Nutr 40: 43-81.

[5] Clemente A (2000) Enzymatic protein hydrolysates in human nutrition. Trends Food Sci Technol 11: 254-262.

[6] Duarte J, Vinderola G, Ritz B, Perdigon G, Matar C (2006) Immunomodulating capacity of commercial fish protein hydrolysate for diet supplementation. Immunobiology 211: 341-350.

[7] Bridson EY, Brecker A (1970) Design and formulation of microbial culture media. Methods in microbiology. Academic Press, New York.

[8] http://web.archive.org/web/20080303135425/http://fsrio.nal.u sda.gov/document_fsheet.php?product_id=169

[9] Aspmo SI, Horn SJ, Eijsink VGH (2005) Hydrolysates from Atlantic cod (Gadus morhua L.) viscera as components of microbial growth media. Process Biochem 40: 3714-3722.
[10] Safari R, Motamedzadegan A, Ovissipour M, Regenstein JM, Gildberg A, et al. (2012) Use of hydrolysates from yellowfin tuna (Thunnus albacares) heads as a complex nitrogen source for lactic acid bacteria. Food Bioproc Tech 5: 73-79.

[11] Fallah M, Bahram S, Javadian SR (2015) Fish peptone development using enzymatic hydrolysis of silver carp byproducts as a nitrogen source in Staphylococcus aureus media. Food Sci Nutr 3: 153-157.

[12] Ryan M, McEvoy E, Duignan S, Crowley C, Fenelon M, et al. (2008) Thermal stability of soy protein isolate and hydrolysate ingredients. Food Chem 108: 503-510.

[13] Dissanayake M, Vasiljevic T (2009) Functional properties of whey proteins affected by heat treatment and hydrodynamic high-pressure shearing. J Dairy Sci 92: 1387-1397.

[14] Nicorescu I, Riaublanc A, Loisel C, Vial C, Djelveh G, et al. (2009) Impact of protein self-assemblages on foam properties. Food Res Int 42: 1434-1445.

[15] Trivedi MK, Nayak G, Patil S, Tallapragada RM, Jana S, et al. (2015) Biofield treatment: An effective strategy to improve the quality of beef extract and meat infusion powder. J Nutr Food Sci 5: 389.

[16] Saad M, Medeiros RD (2012) Distant healing by the supposed vital energy- scientific bases. Complementary therapies for the contemporary healthcare. InTech.

[17] Rubik B (2002) The biofield hypothesis: Its biophysical basis and role in medicine. J Altern Complement Med 8: 703-717.

[18] Garland SN, Valentine D, Desai K, Li S, Langer C, et al. (2013) Complementary and alternative medicine use and benefit finding among cancer patients. J Altern Complement Med 19: 876-881.

[19] Peck SD (1998) The efficacy of therapeutic touch for improving functional ability in elders with degenerative arthritis. Nurs Sci Q 11: 123-132.

[20] Sances F, Flora E, Patil S, Spence A, Shinde V (2013) Impact of biofield treatment on ginseng and organic blueberry yield. Agrivita J Agric Sci 35: 22-29.

[21] Trivedi MK, Patil S, Harish S, Gangwar M, Jana S (2015) Biofield treatment: An alternative approach to combat multidrug-resistant susceptibility pattern of Raoultella ornithinolytica. Altern Integr Med 4: 193.

[22] Trivedi MK, Patil S, Mishra RK, Jana S (2015) Thermal and physical properties of biofield treated bile salt and proteose peptone. J Anal Bioanal Tech 6: 256.

[23] Amin S, Barnett GV, Pathak JA, Roberts CJ, Sarangapani PS (2014) Protein aggregation, particle formation, characterization and rheology. Curr Opin Colloid Interface Sci 19: 438-449.

[24] Khutoryanskiy VV, Nurkeeva ZS, Mun GA, Dubolazov AV (2004) Effect of temperature on aggregation/dissociation behavior of interpolymer complexes stabilized by hydrogen bonds. J Appl Polym Sci 93: 1946-1950.

[25] Aulton ME, Taylor KMG (2013) Aulton's pharmaceutics: The design and manufacture of medicines. (4thedn), Churchill Livingstone, Elsevier.

[26] Suryanarayana C, Norton MG (2013) X-ray diffraction: A practical approach. Springer sciences and business media. 
[27] Kose A, Oncel SS (2015) Properties of microalgal enzymatic protein hydrolysates: Biochemical composition, protein distribution and FTIR characteristics. Biotechnol Rep 6: 137143.

[28] Lambert JB (1987) Introduction to organic spectroscopy. Macmillan, New York, USA.

[29] Snavely DL, Blackburn FR, Ranasinghe Y, Walters VA, del Riego MG (1992) Vibrational overtone spectroscopy of pyrrole and pyrrolidine. J Phys Chem 96: 3599-3605.

[30] Abood NA, Al-Hlfi JAH (2013) Theoretical study of structure and vibrational frequencies of pyrazole and its derivatives, and X-ray structure determination. Misan J Academic Studies 12: $29-40$.
[31] Gill P, Moghadam TT, Ranjbar B (2010) Differential scanning calorimetry techniques: Applications in biology and nanoscience. J Biomol Tech 21: 167-193.

[32] He X, Cao W, Zhao Z, Zhang C (2013) Analysis of protein composition and antioxidant activity of hydrolysates from Paphia undulate. J Food Nutr Res 1: 30-36.

[33] Stodghill SP (2010) Thermal analysis- A review of techniques and applications in the pharmaceutical sciences. American Pharmaceutical Review 13.

[34] Trivedi MK, Nayak G, Patil S, Tallapragada RM, Jana S, et al (2015) Evaluation of the impact of biofield treatment on physical and thermal properties of casein enzyme hydrolysate and casein yeast peptone. Clin Pharmacol Biopharm 4: 138. 